\title{
Geographic separation of stocks of the edible jellyfish Catostylus mosaicus (Rhizostomeae) in New South Wales, Australia
}

\author{
K. A. Pitt*, M. J. Kingsford \\ School of Biological Sciences, Zoology Building, A08 University of Sydney, New South Wales 2006, Australia
}

\begin{abstract}
The population structure of the comnercially harvested jellyfish Catostylus mosaicus (Scyphozoa, Rhizostomeae) was investigated in estuaries and bays in New South Wales, Australia Variations in abundance and recruitment were studied in 6 estuaries separated by distances ranging from 75 to $800 \mathrm{~km}$. Patterns of abundance differed greatly among estuaries and the rank abundance among estuaries changed on 5 out of the 6 times sampling occurred. Great variation in the timing of recruitment was also observed among estuaries. Variations in abundance and recruitment were as extreme among nearby estuaries as distant ones. Broad scale sampling and detailed time series of abundance over a period of 2.7 yr at 2 locations showed no consistent seasonal trend in abundance at 1 location, but there was some indication of seasonality at the second location. At Botany Bay, the abundance of medusae increased with distance into the estuary and on 19 out of the 30 times sampling occurred medusae were found at sites adjacent to where rivers enter the bay. Medusae were found to be strong swimmers and this may aid medusae in maintaining themselves in the upper-reaches of estuaries, where advection from an estuary is least likely. Variability in patterns of abundance and recruitment suggested regulation by processes occurring at the scale of individual estuaries and, combined with their relatively strong swimming ability, supported a model of population retention within estuar. ies. Populations of $C$. mosaicus in individual estuaries and saline lakes in New South Wales should therefore, be considered as separate stock units
\end{abstract}

KEY WORDS: Catostylus mosaicus - Scyphozoa - Population structure - Stock unit - Fishery Abundance $\cdot$ Recruitment

\section{INTRODUCTION}

Species rarely exist as a single, homogeneous population of individuals. Instead, species tend to consist of 'populations of populations' (Levins 1970) whose combined distributions determine the distribution of the species as a whole. Populations may be linked to one another by dispersal of propagules and by migration of adults, or mixing may be minimal and populations may remain reproductively isolated units. Determining population structure is vital to our understanding of population dynamics and enables us to define the unit stock: a population of individuals that are mostly re-

\footnotetext{
•E-mail:kpitt@bio.usyd.edu.au
}

productively isolated from other conspecific populations (Haddon \& Willis 1995). The unit stock is the basic unit of management for commercially harvested species.

Population subdivision may be manifested in a variety of ways. For example, reproductive isolation and the influence of local conditions may result in genetic (Hedgecock 1982, Beacham 1996, Hoskin 1997), morphological (Brewer 1991, Haddon \& Willis 1995) and physiological (Bakhteyeva 1975) differences among conspecific populations (review in Ihssen et al. 1981). Ecological differences may also arise if populations are isolated from one another (Wade 1991), and ecological data may, therefore, be useful in determining the structure of populations (e.g. Casselman et al. 1981). Ecological evidence for population subdivision may be 
direct, such as from tagging studies, or indirect, such as examining the mobility of species at different stages of the life history, or examining the degree of temporal synchronicity in patterns of abundance and recruitment at different spatial scales.

Catostylus mosaicus (Scyphozoa, Rhizostomeae; Quoy \& Gaimard 1824) is a large jellyfish that is common in estuarine waters from 7 to $36^{\circ} \mathrm{S}$ along the northern and eastern coasts of Australia (Southcott 1982). C. mosaicus forms dense aggregations in surface waters (Kingsford 1993) and is one of the most conspicuous pelagic animals in estuaries. Scyphozoan medusae typically have complex life histories that consist of a pelagic medusoid stage, a sexually produced larval stage, and a benthic polypoid phase (Arai 1996). Jellyfish form the basis of a major fishery in Asia (Omori 1981) and worldwide interest in these fisheries is increasing. In 1995 a fishery for C. mosaicus was established in New South Wales. As for any fishery, identification of stock units is crucial for their good management.

The coast of New South Wales is characterised by estuaries, bays and semi-enclosed estuarine lakes. Catostylus mosaicus are generally observed in estuarine areas, rather than in open coastal waters. The population structure of $C$. mosaicus will, therefore, largely depend upon the degree of linkage among estuaries along the coast. Possible models which explain the population structure of C. mosaicus include: (1) Complete retention within a single estuary. Medusae, their propagules and the benthic phase are all retained within a single estuary, with minimal mixing among estuaries. (2) Local dispersal among nearby estuaries on a scale of tens of kilometres. (3) Widespread dispersal along the coast, on scales of hundreds of kilometres, with estuaries being seeded by a common pool of recruits.

Each of the above models would result in different temporal and spatial patterns of recruitment and abundance. For example, complete asynchrony in the timing of recruitment among estuaries and across a range of spatial scales would suggest that populations are not seeded by a common pool of recruits. This, combined with changes in the rank order of abundance among both nearby and distant estuaries, would support Model 1. Synchrony in recruitment and in changes of abundance across small spatial scales, but asynchrony over large scales would suggest limited dispersal (Model 2), and complete synchrony in the timing of recruitment and in changes of abundance through time would suggest widespread dispersal (Model 3). An alternative model, however, may be that abundance and recruitment change in a predictable way with latitude and related environmental gradients (e.g. water temperature). Such variation may occur regard- less of whether medusae are dispersed from, or retained in, estuaries. If this pattern were observed, it would provide little information on the population structure of Catostylus mosaicus.

Patterns of distribution within an estuary should also provide clues to the likelihood of exchange among estuaries. If populations are retained within an individual estuary (Model 1), then to avoid advection, medusae would probably maintain themselves in the inner estuary and rarely be seen near the entrance of the estuary. Conversely, if medusae were dispersed out of the estuary, then medusae should sometimes be found at, or outside the entrance to the estuary (Models 2 and 3).

The objective of this study was to describe patterns of distribution, abundance, size frequency and movements of Catostylus mosaicus that would help to elucidate if linkages exist among estuarine populations. The specific aims were to: (1) Compare patterns of abundance at broad spatial scales and at multiple times. This would determine whether patterns of abundance fluctuated synchronously among estuaries at different spatial scales. (2) Describe patterns of abundance within an estuary and to examine relationships between distance into the estuary and abundance. If medusae were only found in the inner reaches of estuaries, then advection from an estuary was likely to be rare. (3) Compare patterns of size frequency for medusae at broad spatial scales and multiple times. This would determine when recruitment occurred and whether it occurred synchronously among estuaries at various spatial scales. (4) Estimate the swimming speeds of medusae of different sizes. If medusae of a range of sizes were competent swimmers, then they may have been able to use swimming behaviour to retain themselves within an estuary.

\section{MATERIALS AND METHODS}

Study areas. Six estuarine locations, encompassing $6^{\circ}$ of latitude, were selected along the New South Wales coast. The 6 locations were: Lake Wooloweyah, Wallis Lake, Port Stephens, Botany Bay, Lake Illawarra and Batemans Bay (Fig. 1). The physical characteristics of each location are listed in Table 1. Wallis Lake was only included in the study from November 1996 and although data from this location were presented graphically they were not included in statistical analyses. Locations were separated by a range of distances. Lake Wooloweyah and Batemans Bay were nearly $800 \mathrm{~km}$ apart, whereas 2 pairs of locations - Wallis Lake and Port Stephens, and Botany Bay and Lake nllawarra - were separated by 75 to $85 \mathrm{~km}$. Medusae and scyphistomae are thought to be intolerant to 

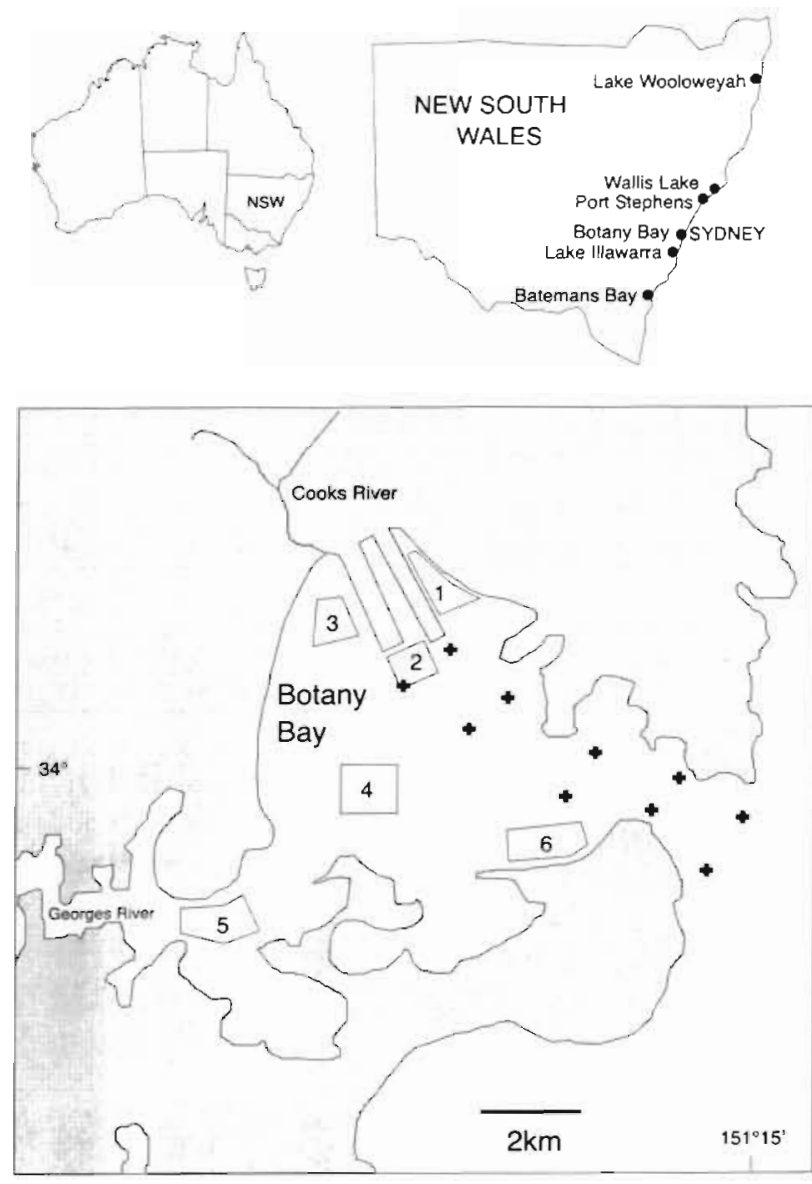

Fig. 1. Study locations in New South Wales. Map of Botany Bay showing the position of 6 sites where abundance was estimated and position of sites ( + ) used to estimate abundance along an estuarine gradient from the inner estuary to the open coast

salinities of less than approximately 8 ppt (Lu et al. 1989) and both temperature and salinity may influence strobilation of polyps (Lu et al. 1989, Rippingale \& Kelly 1995, Purcell 1999). Measurements of salinity and temperature were made at each location, every time sampling was carried out, to determine if $a b$ sence of medusae from a location may have been caused by critical low salinities or water temperatures. Measurements were made using a conductivity, temperature, depth (CTD) device.

Abundance. Hypotheses concerning variation in abundance were tested using visual counts. The number of jellyfish greater than $50 \mathrm{~mm}$ in diameter were counted from the bow of a boat along transects $500 \mathrm{~m}$ long, $3 \mathrm{~m}$ wide and $1 \mathrm{~m}$ deep. Small medusae were not counted since they were translucent and difficult to see. The length of transects was determined by maintaining the boat at a constant speed of $10 \mathrm{~km} \mathrm{~h}^{-1}$ (as determined by a GPS) for $3 \mathrm{~min}$. At all locations current speeds were relatively low and would have had a negligible impact on the length of the transects. Catostylus mosaicus were easily observed to a depth of $1 \mathrm{~m}$ and in a study of the depth distribution of medusae at Lake Illawarra, Kingsford \& Pitt (1998) demonstrated that 87 to $100 \%$ of medusae occurred in the top $1 \mathrm{~m}$ of the water column during the day. The depth of the transects was estimated visually; however to minimise error, the observer initially calibrated depth estimates with a $1 \mathrm{~m}$ pole before counts commenced. Width of transects was determined using a $3 \mathrm{~m}$ pole.

At each location, 6 sites (separated by 0.5 to $5 \mathrm{~km}$ ) were haphazardly selected and 6 transects were run at each site. Multiple sites and replicates were required due to the aggregating behaviour of medusae. This sampling design increased the chances of accurate and precise estimates of abundance being made. The same sites were sampled for the duration of the study to enable comparisons of spatial patterns of abundance within locations through time. Counts were only made when the wind speed was less than 15 knots since wind-generated turbulence appeared to drive medusae below the surface. For comparison of abundance at broad spatial scales (Analysis 1), the abundance of medusae was measured at each location at approximately 4 mo intervals from March 1996. Locations were sampled a total of 6 times. Each time, all locations were sampled within a $3 \mathrm{wk}$ period to minimise the impact of any short-term temporal variation in abundance among estuaries. To determine whether patterns of abundance among adjacent locations (which were sampled within a few days of each other) were

Table 1 Catostylus mosaicus. Summary of the physical characteristics of each location and the amount of medusae harvested. BL: barrier lagoon, DRV: drowned river valley and CL: coastal lagoon for the types of estuaries. The tidal range provides an index of the relative tidal ranges among estuaries. Tidal range was the mean of the maximum daily tidal range for the months March, July and December 1997 (Royal Australian Navy). The tidal height for Wallis Lake was the average tidal range for the years 1993 to 1996 (Manly Hydraulics Laboratory). Tidal range data were unavailable for Lake Wooloweyah and Lake Illawarra, but personal observations suggested that they were similar to the range experienced in Wallis Lake. The amount harvested is the total amount taken since 1995 (P. Dwyer pers. comm.)

\begin{tabular}{|lcccc|}
\hline Location & $\begin{array}{c}\text { Type of } \\
\text { estuary }\end{array}$ & $\begin{array}{c}\text { Depth } \\
\text { range of } \\
\text { sites (m) }\end{array}$ & $\begin{array}{c}\text { Tidal } \\
\text { range } \\
(\mathrm{mm})\end{array}$ & $\begin{array}{c}\text { Amount } \\
\text { harvested } \\
(\mathrm{t})\end{array}$ \\
\hline Lake Wooloweyah & $\mathrm{BL}$ & $1-3$ & $<0.2$ & ca 14 \\
Wallis Lake & $\mathrm{BL}$ & $1-5$ & 0.11 & 32.4 \\
Port Stephens & $\mathrm{DRV}$ & $2-15$ & 1.2 & 0 \\
Botany Bay & $\mathrm{CL}$ & $2-13$ & 1.18 & 0 \\
Lake Illawarra & $\mathrm{BL}$ & $1-4$ & $<0.2$ & 0 \\
Batemans Bay & $\mathrm{DRV}$ & $2-7$ & 1.08 & 0 \\
\hline
\end{tabular}


confounded by short-term (i.e. among days) temporal variation within locations, abundance estimates were repeated within a $3 \mathrm{~d}$ period at each location during August and November 1997 (Analysis 2).

The abundance of medusae was measured more frequently at Botany Bay and Lake Illawarra to provide more detailed information on temporal and small-scale spatial patterns of abundance. At Botany Bay abundance was measured at 3 to 6 wk intervals and abundance measures were made at 8 to $12 \mathrm{wk}$ intervals at Lake Illawarra. Yearly and seasonal variations in abundance at Botany Bay were examined by sampling at 3 random times, each season, over a period of $2 \mathrm{yr}$, beginning in Spring 1996.

Measures of abundance were analysed using analyses of variance (ANOVA). A Cochran's test was used prior to analyses to test data for homogeneity of variances and, if necessary, data were transformed using a $\log _{e}(x+1)$ transformation. If, after transformation, variances were still heterogeneous, ANOVA was still performed since this analysis is robust to heterogeneity of variance; however, the level of significance was set at $\alpha=0.01$ to reduce the risk of Type I errors (Underwood 1997). There were no possible tests for some factors and/or interactions in all analyses. This was not problematic if these factors were involved in significant interactions (Analyses 1 \& 2). If interactions were not significant at $p=0.25$ (Underwood 1997), then appropriate variance components were eliminated to create tests (Analysis 3).

The spatial distribution of medusae within an estuary could reflect the likelihood that medusae would be advected out of an estuary and potentially immigrate to another estuarine system. The distribution and abundance of medusae were measured along an estuarine gradient in Botany Bay. Five sites were established starting at the open coast and finishing in the inner estuary (Fig. 1). Three replicate measures of abundance were made at 2 stations within each site. Abundances were measured by counting the total number of medusae observed along transects $10 \mathrm{~m}$ wide, $50 \mathrm{~m}$ long and $1 \mathrm{~m}$ deep. The length of transects was determined with a float and $50 \mathrm{~m}$ line as described in Kingsford (1993). Counts were repeated 20 times over the period February 1991 to November 1992. Data were very heterogeneous and, therefore, inappropriate for parametric tests. Data were therefore analysed nonparametrically by examining the frequency with which medusae were encountered at each site in order to provide an index of their distribution in the estuary.

Size distribution. Measures of the size distribution of medusae were used to determine the presence and size of cohorts of new recruits. The maximum bell diameter of approximately 200 medusae was measured, using a ruler, at each time of sampling at all locations. Usually the size distribution was measured in the water while snorkelling; however, due to poor visibility at some locations (mainly Lake Wooloweyah and Wallis Lake), medusae were sometimes measured on board the boat. This was justified since there was no difference between measures made in the water or on board the boat (paired $t$-test, $\mathrm{n}=25, \mathrm{p}=0.078$ ). We could identify medusae in situ from a size of $10 \mathrm{~mm}$ bell diameter. Recruitment was defined as occurring, or having recently occurred, if greater than $10 \%$ of the population had a bell diameter less than $100 \mathrm{~mm}$.

Swimming speed. The swimming ability of small $(<80 \mathrm{~mm})$, medium ( 80 to $140 \mathrm{~mm}$ ) and large $(>140 \mathrm{~mm})$ medusae was measured at Lake Illawarra in 1996 $(n=23)$ and $1997(n=20)$. Lake Illawarra was a suitable location to do this since it was shallow, and, as it had only a narrow opening to the sea, it was largely unaffected by tides or other currents which could potentially confound swimming speed estimates. Individual medusae were followed by a snorkeller for approximately $1 \mathrm{~min}$ intervals. A weighted tape measure was dropped to the substratum (approximately $2 \mathrm{~m}$ depth) at the beginning of the time period. After approximately $1 \mathrm{~min}$, the diver swam down and pushed the tape against the substratum, directly beneath the medusa, before reading the distance swum. Any medusae that did not swim in a straight line, or changed depth, were disregarded.

\section{RESULTS}

\section{Patterns of abundance}

The abundance of medusae differed substantially among estuaries each time locations were sampled (Fig. 2). Although the rank order of abundance among estuaries was similar during March and July 1996, for the remaining 4 times of sampling, the rank order of

Table 2. Results of ANOVA for distribution of Catostylus mosaicus among locations along the New South Wales coast ( $\mathrm{n}$ = not significant, $\mathrm{p}<0.05, \cdots p<0.001)$. $\log _{\mathrm{e}}(x+1)$ transformed, Cochran's $C=0.0393^{\circ}, \mathrm{nt}=$ no test, all factors are random. $M S=$ mean square,$F$ vs $=$ denominator mean square

\begin{tabular}{|c|c|c|c|c|c|c|}
\hline \multicolumn{2}{|c|}{ Source of variation } & df & MS & $F$ & $\mathrm{p}$ & $F$ vs \\
\hline 1 & Location & 4 & 333.470 & & & nt \\
\hline 2 & Time & 5 & 15.585 & 0.425 & ns & 4 \\
\hline 3 & Site (Location) & 25 & 8.607 & 1.165 & ns & 5 \\
\hline 4 & Location $\times$ Time & 20 & 36.630 & 4.957 & $\cdots$ & 5 \\
\hline 5 & Site $($ Location $) \times$ Time & 125 & 7.389 & 7.389 & $\cdots$ & 6 \\
\hline 6 & Error & 900 & 1.000 & & & \\
\hline
\end{tabular}




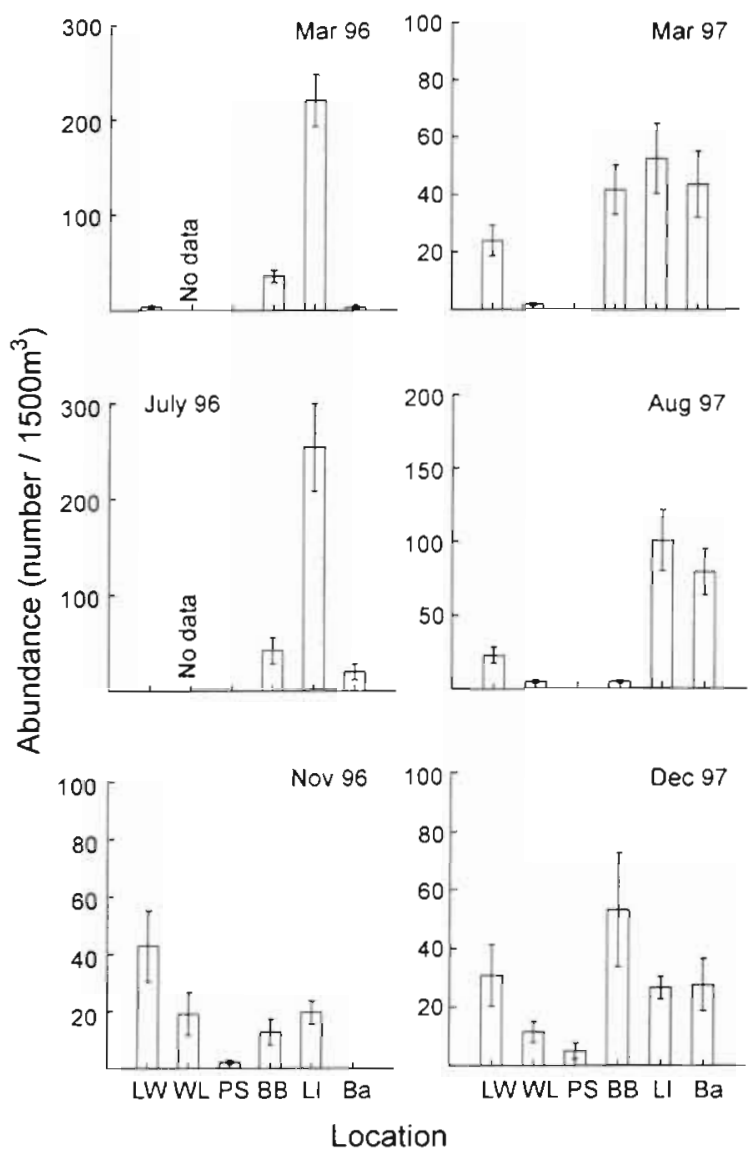

Fig. 2. Catostylus mosaicus. Mean abundance $( \pm \mathrm{SE})$ among estuaries (number per $1500 \mathrm{~m}^{3}$ ) at 6 times of sampling. LW: Lake Wooloweyah, WL: Wallis Lake, PS: Port Stephens, BB:

Botany Bay, LI: Lake Illawarra and Ba: Batemans Bay

abundance differed markedly among locations and this resulted in a significant Location $\times$ Time interaction (Table 2). Temporal variation in abundance within locations was great. For example, at Lake Wooloweyah, medusae were absent in July 1996 and abundant in November 1996 and at Port Stephens medusae were only present in small numbers during November 1996 and December 1997. Changes in abundance were as extreme among nearby estuaries as they were among distant estuaries. For example, on 3 of the 6 times sampling was done, there were more than 5 times as many medusae at Lake Illawarra than at Botany Bay. There was great variation in the salinity and temperature regimes at each location (Table 3). Salinities were most variable within estuarine lakes, and the inner parts of Port Stephens. At the more open estuaries of Botany Bay and Batemans Bay, variation in salinity was minimal. During July 1996, the salinity at Lake Wooloweyah was only $10 \mathrm{ppt}$ and the water temperature was $14^{\circ} \mathrm{C}$. This coincided with a period where medusae were absent from this location (Fig. 2). In contrast, during March 1997, the salinity was also low $(12 \mathrm{ppt})$; however the water temperature was higher $\left(26^{\circ} \mathrm{C}\right)$ and medusae were present in abundances exceeding 20 transect $^{-1}$.

Great variation in abundance was found among sites within locations. For example, at Lake Illawarra in March 1996, the mean abundance of medusae among sites varied from 80 to 540 per $1500 \mathrm{~m}^{3}$. The rank order of abundance among sites, however, varied with each time of sampling, as indicated by the significant Site (Location) $\times$ Time interaction (Table 2). Much variation was also found among transects within a site. It was common, for example, to find no medusae in some transects and in excess of 300 in others. This was indicated by standard errors within sites that were 7 to $87 \%$ of the mean.

Patterns of abundance among adjacent locations were unlikely to be confounded by short-term variation in abundances, as indicated by the non-significant Day (Time) $\times$ Location interaction (Table 4, Fig. 3). The significant Day (Time) $\times$ Site (Location) interaction indicated that medusae moved into or away from a site (distances of hundreds of metres) within $3 \mathrm{~d}$. Despite this, total estimates of abundance at each location were similar for both days sampled.

Table 3. Catostylus mosaicus. Salinity $\left(S_{i} \mathrm{ppt}\right)$ and temperature $\left(T_{;}{ }^{\circ} \mathrm{C}\right)$ measurements for each location, during 6 times of sampling. $n d=$ no data. Shaded areas indicate times when medusae were absent at a location. "Medusae were present at a location, but were not detected by sampling

\begin{tabular}{|c|c|c|c|c|c|c|c|c|c|c|c|c|}
\hline & \multicolumn{2}{|c|}{$\begin{array}{c}\text { Lake } \\
\text { Wooloweyah }\end{array}$} & \multicolumn{2}{|c|}{$\begin{array}{l}\text { Wallis } \\
\text { Lake }\end{array}$} & \multicolumn{2}{|c|}{$\begin{array}{c}\text { Port } \\
\text { Stephens }\end{array}$} & \multicolumn{2}{|c|}{$\begin{array}{c}\text { Botany } \\
\text { Bay }\end{array}$} & \multicolumn{2}{|c|}{$\begin{array}{c}\text { Lake } \\
\text { Illawarra }\end{array}$} & \multicolumn{2}{|c|}{$\begin{array}{c}\text { Batemans } \\
\text { Bay }\end{array}$} \\
\hline & $S$ & $T$ & $S$ & $\mathrm{~T}$ & $\mathrm{~S}$ & $\mathrm{~T}$ & $\mathrm{~S}$ & $T$ & $\mathrm{~S}$ & $T$ & $\mathrm{~S}$ & $\mathrm{~T}$ \\
\hline Mar 96 & 19 & 24 & nd & nd & nd & nd & 35 & 21 & 25 & 18 & 34 & 20 \\
\hline July 96 & 10 & 14 & nd & nd & 33 & 13 & 35 & 13 & 29 & 11 & 34 & 13 \\
\hline Nov 96 & 20 & 25 & 33 & 21 & 33 & 19 & 35 & 18 & 24 & 22 & $32^{\circ}$ & $19^{\circ}$ \\
\hline Mar 97 & 12 & 26 & 26 & 26 & 29 & 25 & 35 & 23 & 28 & 18 & nd & nd \\
\hline Aug 97 & 16 & 15 & 30 & 15 & 26 & 13 & 34 & 16 & 26 & 13 & 34 & 14 \\
\hline Dec 97 & 23 & 25 & 34 & 23 & 34 & 24 & 35 & 25 & 26 & 23 & 34 & 20 \\
\hline
\end{tabular}




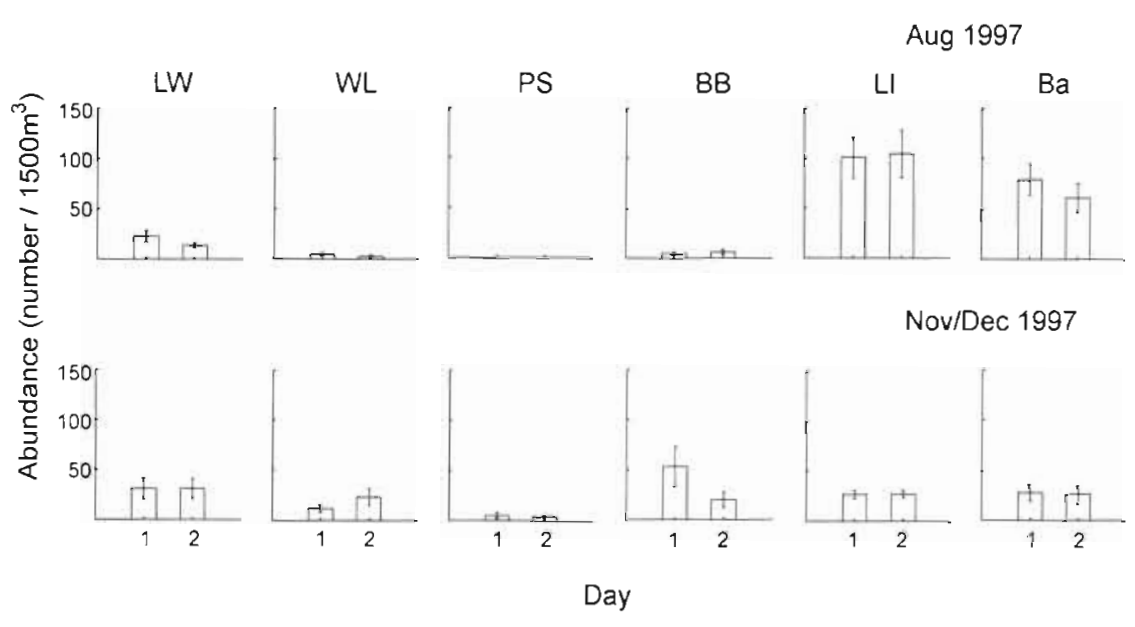

Fig. 3. Catostylus mosaicus. Mean abundance (number per $1500 \mathrm{~m}^{3}, \pm \mathrm{SE}$ ) measured twice within $3 \mathrm{~d}$ at each estuary. See Fig. 2 for site abbreviations

Table 4. Catostylus mosaicus. Results of ANOVA for short-term temporal replication of abundance estimates of medusae among locations. (ns = not significant, ${ }^{\circ} p<0.05$. $\cdots p<0.001) . \log _{e}(x+1)$ transformed, Cochran's $C=0.0448^{\circ}$, nt $=$ no test, all factors are random. $\mathrm{MS}=$ mean square, $F$ vs = denominator mean square

\begin{tabular}{|c|c|c|c|c|c|c|}
\hline & Source of variation & df & MS & $F$ & $\mathrm{p}$ & $F$ vs \\
\hline 1 & Location & 5 & 159.004 & & & nt \\
\hline 2 & Time & 1 & 0.287 & & & nt \\
\hline 3 & Day (Time) & 2 & 0.784 & 0.397 & ns & 6 \\
\hline 4 & Site (Location) & 30 & 13.707 & 1.328 & ns & 7 \\
\hline 5 & Location $\times$ Time & 5 & 36.086 & & & nt \\
\hline 6 & Day (Time) $\times$ Location & 10 & 1.974 & 0.569 & ns & 8 \\
\hline 7 & Time $\times$ Site (Location) & 30 & 10.325 & 2.974 & $\cdots$ & 8 \\
\hline 8 & Day $($ Time $) \times$ Site (Location) & 60 & 3.472 & 3.162 & $\cdots$ & 9 \\
\hline 9 & Residual & 720 & 1.098 & & & \\
\hline
\end{tabular}

Table 5. Catostylus mosaicus. Results of ANOVA for distribution of medusae in Botany Bay. (ns = not significant, $" p<0.05, \cdots p<0.01, \cdots p<0.001)$. $\log _{e}(x+1)$ transformed, Cochran's $C=0.0280 \mathrm{~ns}$, nt $=$ no test, parentheses indicate tests created by elimination of non-significant terms. The factor 'Season' is fixed, all others are randon. $M S=$ mean square, $F$ vs = denominator mean square

\begin{tabular}{|lrrrrr|}
\hline Source of variation & df & MS & $F$ & p & Fvs \\
\hline 1 Year & 1 & 13.608 & & & $n$ nt \\
2 Season & 3 & 30.091 & & & nt \\
3 Site & 5 & 66.155 & 7.20 &. & 6 \\
4 Year $\times$ Season & 3 & 49.253 & $(4.62)$ &. & 15 \\
5 Time (Year $\times$ Season) & 16 & 10.665 & 1.94 &. & 8 \\
6 Year $\times$ Site & 5 & 9.190 & 1.67 & ns & 8 \\
7 Season $\times$ Site & 15 & 13.645 & 2.48 & $\cdots$ & 8 \\
8 Site $\times$ Time (Year $\times$ Season) & 80 & 5.508 & 4.14 & $\ldots$ & 10 \\
9 Year $\times$ Season $\times$ Site & 15 & 4.489 & 0.82 & ns & 8 \\
10 Residual & 720 & 1.331 & & & \\
\hline
\end{tabular}

Within Botany Bay, there were seasonal differences in the abundance of medusae; however the pattern of abundance among seasons varied each year, as indicated by the significant Year $x$ Season interaction (Table 5, Fig. 4). Great variation was detected in abundance among sites, but the rank order of abundance among sites changed with each time of sampling, as demonstrated by the significant Site $\times$ Time (Season) interaction (Table 5). Despite the order of abundance varying among sites, on 19 of the 30 times sampling was done, the greatest abundances of medusae were found at either Site 3 or Site 5, in the innerreaches of the estuary (Fig. 1). Both these sites were close to riverine input. A similar trend was observed at other estuaries with significant riverine input (Wallis Lake, Port Stephens and Batemans Bay). At Lake Wooloweyah and Lake lllawarra, however, both of which are fed by small creeks, there were no consistent trends in the abundance of medusae among sites. Medusae were present in Botany Bay throughout the study and there was great variation in the abundance of medusae at each time of sampling (Fig 5). Abundances at Lake Illawarra were typically higher than at Botany Bay and there appeared to be a trend for medusae to be more abundant between March and July. A large input of recruits during May 1998 resulted in enormous densities of medusae in the lake. There was poor correlation in patterns of abundance between Botany Bay and Lake Illawarra, despite these locations being separated by approximately $85 \mathrm{~km}$. Although there were 3 main peaks in abundance at each location, there was imper. fect overlap among peaks and abundance maxima varied by up to 4 mo. For example, a large peak in abundance occurred in Botany Bay in January 1998, but the 
abundance of medusae in Lake Illawarra did not increase until May 1998 (Fig. 5).

Measurements of the distribution of medusae along an estuarine gradient from the open coast, to the inner reaches of Botany Bay, demonstrated that medusae were most frequently encountered at the inner-most sites within the estuary (Fig. 6). No medusae were sighted at the open coast site during 20 times of sampling and medusae were only present at Site 4 (between the heads of Botany Bay) on 4 occasions. Although medusae were occasionally seen in the outer regions of the bay, they were never found in abundances greater than 10 transect $^{-1}$ and medusae were only frequently found in abundance at the inner-most site (Fig. 6).

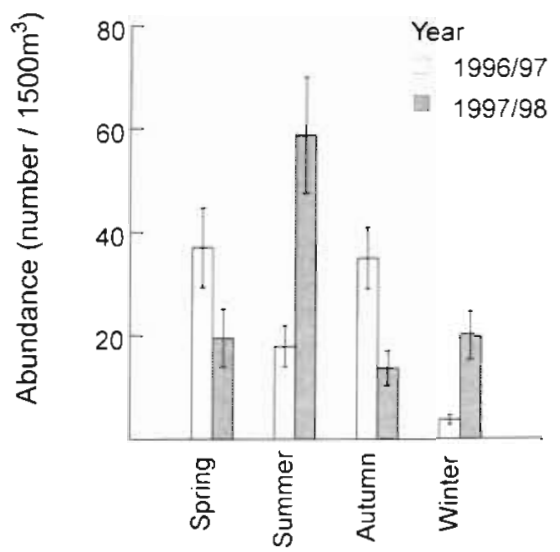

Fig. 4. Catostylus mosaicus. Yearly and seasonal variation in the mean abundance (number per $1500 \mathrm{~m}^{3}, \pm \mathrm{SE}$ ) of medusae in Botany Bay

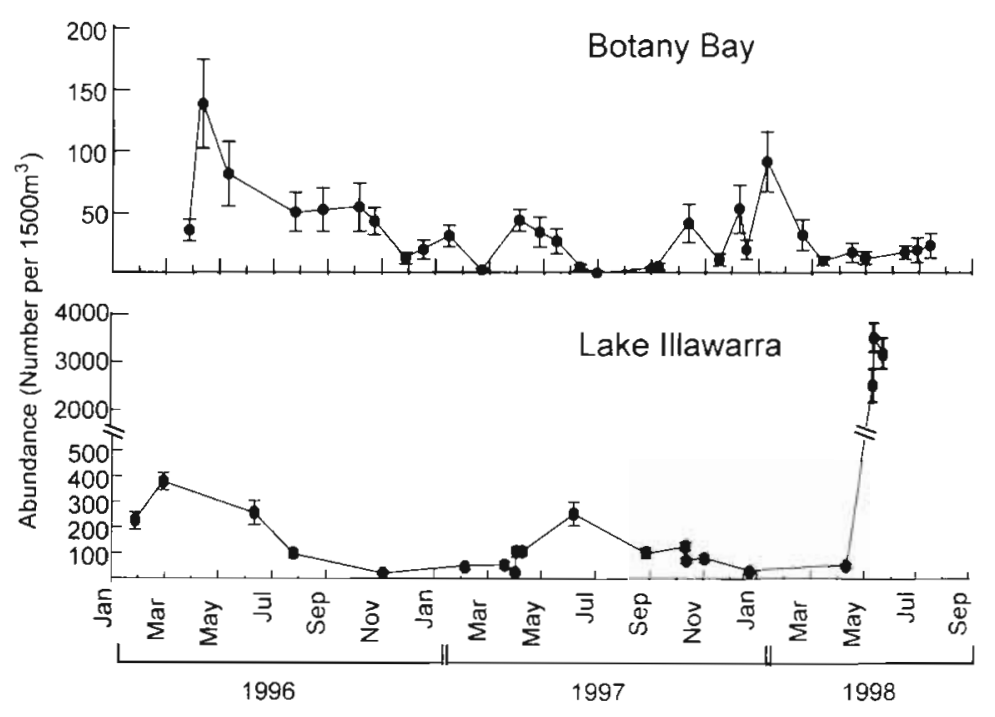

Fig. 5. Catostylus mosaicus. Time series of mean abundance (number per $1500 \mathrm{~m}^{3}, \pm \mathrm{SE}$ ) of medusae in Botany Bay and Lake lllawarra (a) Present / Absent

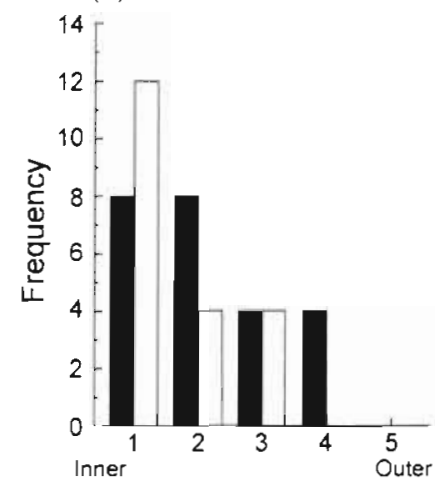

(b) Mean $>10$

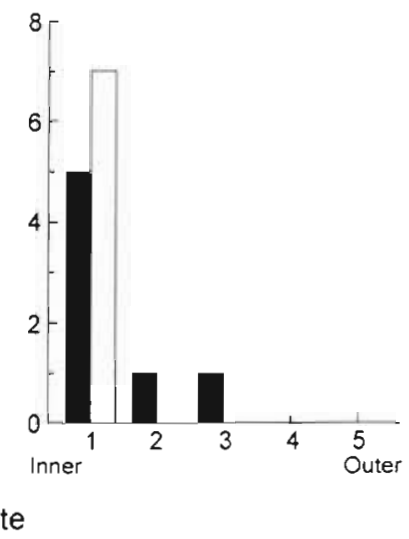

Fig. 6. Catostylus mosaicus. Distribution of medusae in Botany Bay. (a) Frequency with which medusae were observed at replicate stations within sites positioned along a gradient from the inner estuary (1) to the open coast (5). (b) Frequency with which medusae were observed in abundances $>10$ transect $^{-1}$ at each site

\section{Size distribution}

The timing of recruitment varied among locations (Fig 7). For example, during November 1996 recruitment only occurred at Lake Wooloweyah, and during March 1997 new recruits were observed at Botany Bay and Lake Illawarra, but recruits were not observed elsewhere. The extent of geographic separation among locations did not appear to influence the timing of recruitment as recruitment was asynchronous even among locations separated by less than $100 \mathrm{~km}$ (e.g. Wallis Lake and Port Stephens). Although synchronous recruitment was shown to occur at Botany Bay and Lake Illawarra (approximately $85 \mathrm{~km}$ apart) during March 1997, during December 1997 recruitment occurred at Botany Bay, but not at Lake Illawarra. Moreover, recruitment did not occur at Lake Illawarra until over 2 mo later (Kingsford \& Pitt 1998). Although the timing of recruitment varied among locations, recruitment was generally observed during the March and November sampling times. An exception to this was Wallis Lake, where recruits were only found during August 1997.

The timing of recruitment was equally variable within locations and was not consistent among years (Fig 7). For example, at Lake Wooloweyah, major recruitment events occurred during March and November 1996 but in 1997 recruitment was only observed during November. Similarly, at Botany Bay, recruitment was observed during March and De- 


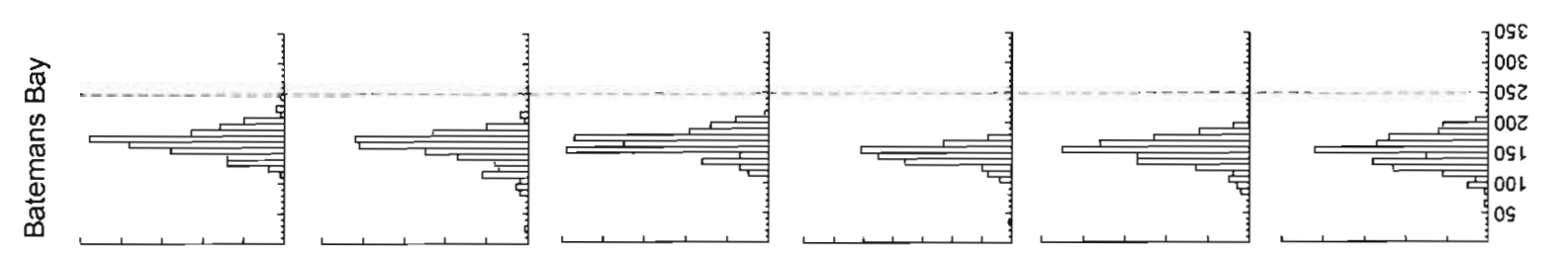

0
$\pi$
3
0
0
0
0
0
0
0
0
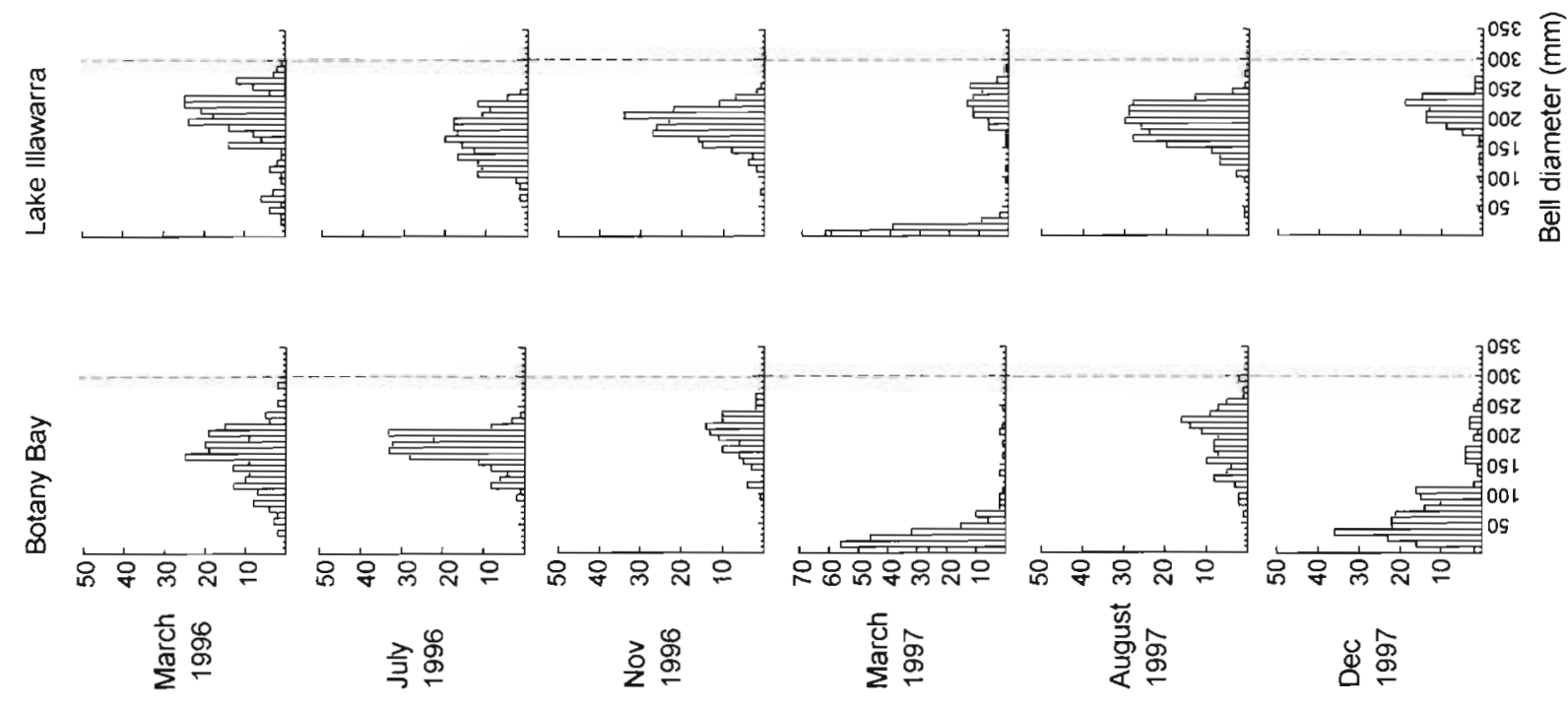

喜部

喜量

号哣
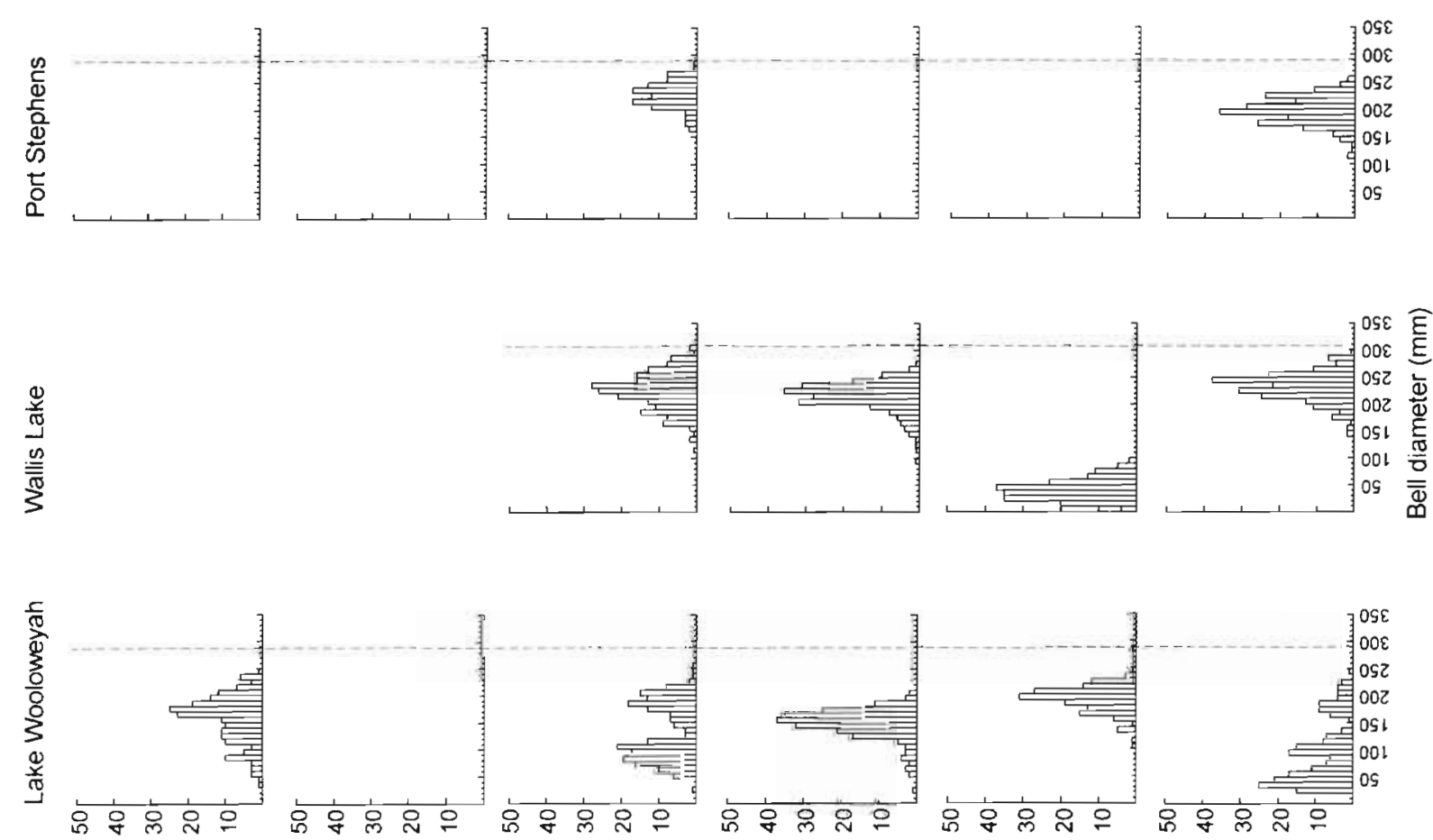

喜量

拿量

辛兽

喜蒿

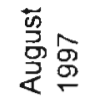

宗盒

(1) 
cember 1997, and although few small medusae were present in March 1996, the wide size distribution of medusae suggested that recruitment had been occurring prior to sampling. Consequently the timing of recruitment was sometimes inconsistent within a location.

Differences were also observed in the maximum size that medusae grew to among locations (Fig. 7). At Batemans Bay few medusae greater than $200 \mathrm{~mm}$ bell diameter were found and the maximum size recorded at this location was $245 \mathrm{~mm}$. In contrast, the largest medusa found at Wallis Lake was $305 \mathrm{~mm}$ and although similar maximum values were found at Botany Bay and Lake Illawarra, medusae at Wallis Lake were consistently larger than at other locations.

\section{Swimming speed}

Large medusae were able to swim at speeds exceed ing $6 \mathrm{~m} \mathrm{~min}^{-1}$ (Fig. 8). Although the swimming ability of small ( $<80 \mathrm{~mm}$ diameter) medusae was considerably less than large individuals, small medusae could still swim in excess of $2 \mathrm{~m} \mathrm{~min}^{-1}$. Variation in swimming speeds within a size class was small, with standard errors being 5 to $10 \%$ of the mean. The swimming abilities of large and small medusae were similar during 1996 and 1997.

\section{DISCUSSION}

\section{Patterns of abundance}

Catostylus mosaicus were found in abundance along the coast of New South Wales and high concentrations were found at some locations at all times of the year.

1996

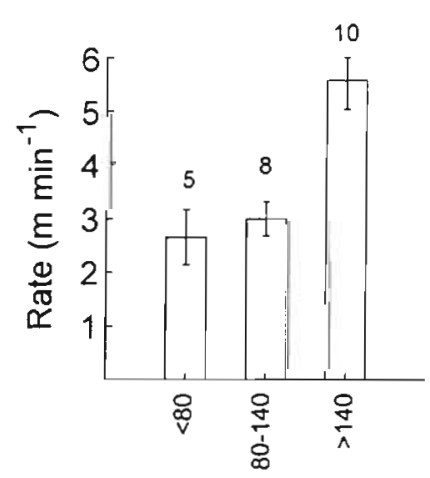

Bell diameter $(\mathrm{mm})$
1997

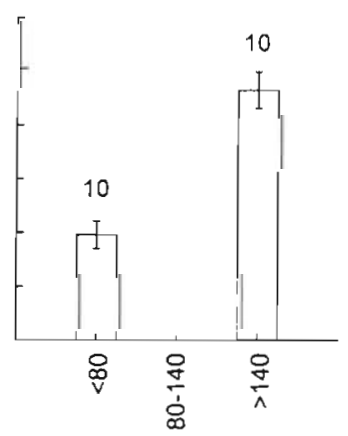

Fig. 8. Catostylus mosaicus. Swimming ability of medusae $\left(\mathrm{m} \mathrm{min}^{-1}\right.$ ) from small $(<80 \mathrm{~mm}$ ), medium (80 to $140 \mathrm{~mm}$ ) and large ( $>140 \mathrm{~mm}$ ) size classes. Numbers above bars indicate $n$
Estimates of the abundance of scyphozoans have been made in other places (e.g. Van der Veer \& Oorthuysen 1985, Lucas \& Williams 1994), but sampling at multiple places and times is rare. There were no consistent seasonal trends in abundance in Botany Bay, since the pattern of abundance among seasons differed during each year. This contrasts with several other studies which have demonstrated seasonal variation in abundance (e.g. Gröndahl 1988, Garcia 1990, Lucas \& Williams 1994). In some studies, however, measures of abundance have been crude (Brewer 1989, Rippingale \& Kelly 1995). Over 3 yr of sampling in Southampton Water, Lucas \& Williams (1994) found consistent seasonal patterns in the abundance of Aurelia aurita. A. aurita was present for approximately 3 to 4 mo over spring and summer. Similar seasonal patterns of abundance of $A$. aurita were also observed from 4 yr of sampling in the Gullmar Fjord, Sweden (Gröndahl 1988). Garcia (1990), in a study in Puerto Rico, also suggested that the rhizostome Phyllorhiza punctata displayed seasonality, with medusae being most abundant during summer months. Temporal variation in Garcia's study, however, may not be seasonal, as sampling was only done over a period of 12 mo and sampling for periods of greater than 1 yr is required to determine generality of seasonal patterns (as was clearly demonstrated by the present study). Although the above studies examined patterns of abundance at multiple sites, conclusions regarding seasonality were based on samples taken at only 1 location. Indeed Lucas (1996) subsequently found that $A$. aurita displayed no clear seasonal trends in abundance at an enclosed brackish lake, only $30 \mathrm{~km}$ from Southampton Water. This contrasted with the highly seasonal pattern found in Southampton Water and indicated that the dynamics of populations of $A$. aurita differed greatly over small spatial scales (Lucas et al. 1997). Although no consistent seasonal patterns were observed at Botany Bay during the current study, detailed sampling over 2.7 yr suggested that $C$. mosaicus displayed sesasonality at Lake Illawarra, with medusae being more abundant during spring and winter. These observations indicated that seasonal trends in abundance may vary among locations. It is clearly important, therefore, to sample at multiple locations before drawing conclusions regarding the generality of seasonal patterns of abundance.

The lack of medusae at Lake Wooloweyah during July 1996 was correlated with a period of low salinity and temperature (Table 3). Salinities of $10 \mathrm{ppt}$ are considered to be close to the lower tolerance limits of some species of scyphistomae and medusae (Lu et al. 1989, Rippingale \& Kelly 1995, Purcell et al. 1999). During March 1997, the salinity was only 12 ppt; however medusae were still present. At the other locations, tem- 
perature and salinity regimes remained within a range generally considered to be non-lethal; however medusae were sometimes absent from these locations. Absence of medusae cannot, therefore, be solely attributed to critical salinities or temperatures.

The New South Wales jellyfish fishery operates between November and May. During the first 2 seasons (1995/96 and 1996/97), fishing was restricted to waters north of Broken Bay (approximately $40 \mathrm{~km}$ north of Sydney). The total catch for the first 2 seasons was $47 \mathrm{t}$ (P. Dwyer pers. comm.). The majority of this catch came from the Wallis Lake region (33 t), with the remaining $14 \mathrm{t}$ being taken from the Clarence River, which is connected via channels to Lake Wooloweyah. Variation in the abundances of medusae at Wallis Lake may have been confounded by harvesting; however, as Wallis Lake was not included in statistical analyses, the harvest from Wallis Lake did not confound interpretation of analyses. The relatively small harvest taken from the Clarence River was unlikely to greatly influence estimates of abundance made in Lake Wooloweyah. In October 1997 the geographic bounds of the fishery were extended to include the entire New South Wales coast; however catches have remained small (approximately $10 \mathrm{t}$ ) and have mainly been taken from estuaries other than those sampled during this study. Consequently, data from all locations, excepting Wallis Lake and Lake Wooloweyah, represent pre-harvest data.

\section{Linkages among estuaries}

Much variation in the pattern of abundance among estuaries was found during this study, with the rank order of abundance among estuaries differing on 5 of the 6 times sampling occurred. There were also no consistent lags in abundance among estuaries that would indicate latitudinal trends in abundance. Lack of synchrony in abundance among estuaries was particularly apparent at Botany Bay and Lake Illawarra, where more frequent temporal sampling was done. At these locations, large fluctuations in abundance were shown to occur over short periods of time. Scyphozoan medusae grow rapidly (Van der Veer \& Oorthuysen 1985, Kingsford \& Pitt 1998) and are probably shortlived. Consequently, large changes in abundance may occur quickly. The asynchronous change in abundance among estuaries suggested that factors operating at the scale of individual estuaries appeared to determine the abundance of medusae at each location. Linkage among estuaries separated by tens of kilometres was, therefore, probably minimal. These data provide support for Model 1: that populations were retained within individual estuaries.
In Botany Bay there was a persistent trend for medusae to be found in greatest abundance in the upper reaches of the estuary. In 20 times of sampling, no medusae were found outside the entrance of Botany Bay and the abundance of medusae increased with distance into the estuary. Although very small medusae (ephyrae) would have been too small to count, ephyrae have a very rapid growth rate (Gröndahl \& Hernroth 1987). If ephyrae were being advected from estuaries, therefore, we would consider that some small medusae would occasionally have been seen on the open coast. These results suggested that few medusae were found in areas where they were vulnerable to advection out of the bay and that the majority of medusae in the population were maintained in areas where advection was unlikely. Although it was not formally tested, similar patterns were observed at other locations with significant riverine input (Wallis Lake, Port Stephens and Batemans Bay). Medusae were most frequently found in abundance at sites adjacent to where rivers entered the estuaries. Salinities in the inner areas of estuaries are typically lower than near the entrances of estuaries (Kingsford \& Suthers 1996). Medusae may, therefore, have an affiliation with low salinities which attracts them to the inner areas of estuaries. At Lake Wooloweyah and Lake Lllawarra, however, the distribution of medusae among sites appeared to vary more randomly through time. At both these locations, the salinity was consistently lower than that of normal seawater and consequently the salinity gradient between the outer and inner estuary may not have been as marked, and so may not have provided such a strong cue to the medusae. These results concurred with observations made by Lucas \& Williams (1994). They observed that the abundance of Aurelia aurita increased with distance into Southampton Water and concluded that this was evidence that populations of $A$. aurita were endemic to that estuary. The maintenance of medusae of Catostylus mosaicus in the upper reaches of estuaries that had significant riverine input and exchange with the sea supported the model of population retention and minimal exchange among estuaries (Model 1).

The degree of retention within estuaries may vary according to local topography, tidal range and related tidal currents. In relatively enclosed lakes (e.g. Lake Wooloweyah and Lake Illawarra) current speeds are very low and medusae of a wide size range would have little difficulty swimming against the currents. In contrast, in more open estuarine systems, such as Botany Bay, currents speeds of 10 to $80 \mathrm{~cm} \mathrm{~s}^{-1}$ have been measured (M.J.K. unpubl. data). Although current speeds may be lower in the upper reaches of a bay, the chances of expatriation via currents will be greater than in semi-enclosed lakes. Similarly, stochastic ran- 
dom events that influence enclosed waters with significant riverine input (such as heavy rain) may have a role in expatriation (Kingsford \& Suthers 1994). Batemans Bay was perhaps the most interesting location in that medusae were most common within the entrance of the Clyde River. On flood tides medusae were 2 to $5 \mathrm{~km}$ from the open coastal waters while on the ebb they were found at sites close to the ocean. We would predict, therefore, that expatriation is more likely at this type of location

Like most zooplankton, medusae frequently form dense aggregations, which results in a patchy distribution (Omori \& Hamner 1982). Such patchiness was exhibited by Catostylus mosaicus and reflected by the large variation in abundance that occurred at the scale of sites within estuaries, as well as among replicate transects. Aggregation of medusae may be facilitated by oceanographic features (Larson 1992), but the distribution of large plankton, in particular, may not be explained by current movement alone (Hamner et al. 1994). Organisms are likely, therefore, to use a combination of behaviour and oceanographic features to control their distribution. Rhizostome jellyfish are pelagic for a significant portion of their life history. Measurements of the swimming ability of $C$. mosaicus, made across a range of size classes, showed that even small medusae (less than $80 \mathrm{~mm}$ diameter) could swim in excess of $2 \mathrm{~m} \mathrm{~min} \mathrm{~m}^{-1}$. Medusae have been demonstrated to orientate their swimming in response to cues such as shadows (Hamner \& Hauri 1981) and wind or surface waves (Shanks \& Graham 1987). In Saanich Inlet, Canada, Aurelia aurita appeared to direct its swimming by using the sun as a compass (Hamner et al. 1994). This behaviour was postulated as being a mechanism by which medusae retained themselves within the fjord. The swimming ability of C. mosaicus increased with size. C. mosaicus has a rapid growth rate and can attain a bell diameter of 150 to $200 \mathrm{~mm}$ diameter within 3 mo (Kingsford \& Pitt 1998); thus medusae rapidly pass through the most weakly swimming stage of the life history. The relatively strong swimming ability of $C$. mosaicus, across a range of sizes suggested that medusae were not passive plankters and that they may use a combination of swimming and behaviour to be retained within an estuary (Model 1).

\section{Recruitment}

The timing of recruitment differed substantially among and within estuaries. If there was considerable advection of larvae or ephyrae from estuaries, then some degree of synchrony in the timing of recruitment across small spatial scales would be expected. Simi- larly, if recruitment was influenced by seasonal factors, then this should be reflected by medusae in different estuaries passing through similar cycles of recruitment and growth. Differences in the timing of recruitment over small spatial scales and within estuaries suggested that strobilation may have depended on an environmental cue that varied over the scale of individual estuaries. Estuaries were probably, therefore, self-seeding. This supported the model of population retention within an estuary (Model 1). Only one other study has examined variation in recruitment over small spatial scales. Lucas et al. (1997), similarly found that the timing of recruitment of Aurelia aurita differed substantially between Southampton Water and Horsea Lake, an enclosed, brackish lake that was only $30 \mathrm{~km}$ from Southampton Water.

The size distribution of medusae was measured at all 6 locations over a $3 \mathrm{wk}$ period. The rapid growth rate of Catostylus mosaicus may have partly confounded comparisons of the timing of recruitment among estuaries. Large differences in the size distribution of medusae however, were observed among adjacent locations. Adjacent locations were sampled within periods of 4 to $5 \mathrm{~d}$, so the observed differences were unlikely to have been affected by growth of the medusae.

\section{Stock identification}

Ecological approaches have been used to identify different stocks of marine organisms. For example, data on patterns of drift larvae, morphometrics and growth have been used to discriminate stocks of fishes (Casselman et al. 1981, Haddon \& Willis 1995). Furthermore, advances in the field of genetics (such as the use of microsatellites) have increased the sensitivity of genetic techniques and consequently genetic techniques are increasingly being used as tools for identifying stocks (e.g. Beacham 1996). Genetics are able to readily distinguish among populations which are reproductively isolated from one another, and whose genomes reflect this isolation. For mobile species however, the successful migration of a small number of individuals to other populations may result in sufficient gene flow to prevent genetic techniques from discriminating among populations. This is particularly relevant for species such as Catostylus mosaicus which can reproduce rapidly via asexual means. It is important therefore, to distinguish between the concept of genetic stocks and ecological stocks, as ecological differences among populations may not be reflected genetically. A species may show a high degree of panmixis over spatial scales of tens to hundreds of kilometres, but great variation in local recruitment or a high level of self-seeding and restricted movement of adults may 
result in population units as determined by ecological processes. There may be sufficient genetic exchange among estuaries every few years, but this gives very little understanding of variation in numbers of medusae within an area such as an estuary or lake. For fisheries management, differences in the timing and magnitude of recruitment and subsequent changes of biomass available to the fishery will be most relevant. In ecological terms, we view the metapopulation of C. mosaicus as consisting of all individuals in the geographic range of the species (Torres Strait to Port Phillip Bay; Southcott 1982). Populations within bays and estuaries form mesopopulations that correspond to fisheries stocks.

\section{Conclusion}

In conclusion, differences in the abundance and recruitment of Catostylus mosaicus across a range of spatial scales suggested geographic separation of populations of jellyfish over scales of tens of kilometres. The unit stock for the New South Wales jellyfish fishery should, therefore, be considered to be a population within an estuary. This conclusion is probably also relevant to species in other parts of the world, particularly where populations appear to be topographically confined, such as in fjords (Gröndahl 1988, Hamner et al. 1994) and estuarine lakes with restricted access to the open ocean (Hamner \& Hauri 1981, Garcia 1990, Lucas et al. 1997). The New South Wales jellyfish fishery is currently managed as a single stock, with 1 quota set for the entire fishery. Such management potentially allows for intense fishing to occur within single estuaries. Fisheries records from 1996 to 1998 indicated that, although the catch was not great, the majority of the catch was taken from a single estuary (Wallis Lake). This estuary was in close proximity to a processing facility. Medusae must be processed within hours of harvest and raw product cannot be transported. Areas that develop processing facilities are, therefore, likely to be subject to intense fishing pressure. If dispersal among estuaries is minimal, then recolonisation of estuaries that have been depleted of jellyfish is likely to be slow. Management policies should reflect the stock unit size. Ideally, for C. mosaicus, management should, therefore, occur at the scale of individual estuaries. Great variation in the abundance of medusae among estuaries suggests that quotas need to be assigned based on the abundance of medusae at each location. Short-term change in abundance of medusae within a location suggests that frequent surveys and flexible management policies are required to enable managers to quickly respond to changes in abundance.
Acknowledgements. We would like to thank Environment Australia for funding this project. L. Gershwin and 4 anonymous reviewers made helpful comments on the manuscript.

\section{LITERATURE CITED}

Arai MN (1996) A functional biology of Scyphozoa. Chapman and Hall, London

Bakhteyeva VT (1975) Cation concentration in the blood serum of the sockeye, Oncorhynchus nerka, of different intraspecific groups. J Ichthyol 15:980-984

Beacham TD (1996) The use of minisatellite DNA variation for stock identification of chum salmon, Oncorhynchus keta. Fish Bull 94:611-627

Brewer RH (1989) The annual pattern of feeding, growth, and sexual reproduction in Cyanea (Cnidaria: Scyphozoa) in the Niantic River estuary, Connecticut. Biol Bull 176: $272-281$

Brewer RH (1991) Morphological differences between, and reproductive isolation of 2 populations of the jellyfish Cyanea in Long Island Sound, USA. Hydrobiologia 216/ $217: 471-477$

Casselman JM, Collins JJ, Crossman EJ, Ihssen PE, Spangler GR (1981) Lake whitefish (Coregonus clupeaformis) stocks of the Ontario waters of Lake Huron. Can J Fish Aquat Sci 38:1772-1789

Garcia JR (1990) Population dynamics and production of Phyllorhiza punctata (Cnidaria: Scyphozod) in Laguna Joyuda, Puerto Rico. Mar Ecol Prog Ser 64:243-251

Gröndahl F (1988) A comparative ecological study on the scyphozoans Aurelia aurita, Cyanea capillata and C. lamarckii in the Gullmar Fjord, western Sweden, 1982 to 1986. Mar Biol 97:541-550

Gröndahl R, Hernroth L (1987) Release and growth of Cyanea capillata (L.) ephyrae in the Gullmar Fjord, western Sweden. J Exp Mar Biol Ecol 106:91-101

Haddon M, Willis TJ (1995) Morphometric and meristic comparison of orange roughy (Hoplostethus atlanticus: Trachichthyidae) from the Puysegur Bank and Lord Howe Rise, New Zealand, and its implications for stock structure. Mar Biol 123:19-27

Hamner WM, Hauri IR (1981) Long-distance horizontal migrations of zooplankton (Scyphomedusae: Mastigias). Limnol Oceanogr 26:414-423

Hamner WM, Hamner PP, Strand SW (1994) Sun-compass migration by Aurelia aurita (Scyphozoa): population retention and reproduction in Saanich Inlet, British Columbia. Mar Biol 119:347-356

Hedgecock D (1982) Genetic consequences of larval retention: theoretical and methodological aspects. In: Kennedy VS (ed) Estuarine comparisons. Academic Press, New York, p 553-568

Hoskin, MG (1997) Effects of contrasting modes of larval development on the genetic structures of populations of three species of prosobranch gastropods. Mar Biol 127:647-656

Ihssen PE, Booke HE, Casselman JM, McGlade JM, Payne NR, Utter FM (1981) Stock identification: materials and methods. Can J Fish Aquat Sci 38:1838-1855

Kingsford MJ (1993) Biotic and abiotic structure in the pelagic ienvironment: importance to small fishes. Bull Mar Sci 53:393-415

Kingsford MJ, Pitt KA (1998) Research on the timing of reproduction, abundance, stock assessment and genetics of the edible jellyfish Catostylus mosaicus in New South Wales waters. Unpublished Report, University of Sydney, Australia 
Kingsford MJ, Suthers IM (1994) Dynamic estuarine plumes and fronts: importance to small fish and plankton in coastal waters of NSW, Australia. Cont Shelf Res 14:655-672

Kingsford MJ, Suthers IM (1996) The influence of tidal phase on patterns of ichthyoplankton abundance in the vicinity of an estuarine front, Botany Bay, Australia. Estuar Coast Shelf Sci 43:33-54

Larson RJ (1992) Riding Langmuir circulations and swimming in circles: a novel form of clustering behaviour by the scyphomedusa Linuche unguiculata. Mar Biol 112:229-235

Levins R (1970) Extinction. Lect Math Life Sci 2:75-107

Lu N, Liu C, Guo P (1989) Effect of salinity on larva of edible medusae (Rhopilema esculenta Kishinouye) at different development phases and a review on the cause of jellyfish resources falling greatly in Liaodong Bay. Acta Ecol Sin 9(4):304-309

Lucas CH (1996) Population dynamics of Aurelia aurita (Scyphozoa) from an isolated brackish lake, with particular reference to sexual reproduction. J Plankton Res 18: $987-1107$

Lucas CH, Williams JA (1994) Population dynamics of the scyphomedusa Aurelia aurita in Southampton Water J Plankton Res 16:879-95

Lucas CH, Hirst AG, Williams JA (1997) Plankton dynamics and Aurelia aurita production in two contrasting ecosystems: comparisons and consequences. Estuar Coast Shelf Sci 45:209--219

Omori M (1981) Edible jellyfish (Scyphomedusae: Rhizostomeae) in the Far East waters: a brief review of the biol-

Editorial responsibility: Otto Kinne (Editor),

Oldendorf/Luhe. Germany ogy and fishery. Bull Plankton Soc Jpn 28:1-11

Omori M, Hamner WM (1982) Patchy distribution of zooplankton: behaviour, population assessment and sampling problems. Mar Biol 72:193-200

Purcell JE, White JR, Nemazie DA, Wright DA (1999) Temperature, salinity and food effects on asexual reproduction and abundance of the scyphozoan Chrysaora quinquecirrha. Mar Ecol Prog Ser 180:187-196

Quoy JRC, Gaimard JP (1824) Voyage autour du monde executé sur l'Uranie et al Physicienne 817-1820. Zoologie IV:712

Rippingale RJ, Kelly SJ (1995) Reproduction and survival of Phyllorhiza punctata (Cnidaria: Rhizostomeae) in a seasonally fluctuating salinity regime in Western Australia. Mar Freshw Res 46:1145-1151

Shanks AL, Graham WM (1987) Orientated swimming in the jellyfish Stomolopus meleagris L. Agassiz (Scyphozoan: Rhizostomida). J Exp Mar Biol Ecol 108:159-169

Southcott RV (1982) Jellyfishes (Classes Scyphozoa and Hydrozoa). In: Shepherd SA, Thomas IM (eds) Marine invertebrates of Southern Australia. Part I. Government Printer, Adelaide, p 115-159

Underwood AJ (1997) Experiments in ecology. Cambridge University Press, Cambridge

Van der Veer HW, Oorthuysen W (1985) Abundance, growth and food demand of the scyphomedusa Aurelia aurita in the western Wadden Sea. Neth J Sea Res 19:38-44

Wade MJ (1991) Genetic variance for rate of population increase in natural populations of flour beetles, Tribolium spp. Evolution 45:1574-1584

Submitted: January 14, 1999; Accepted: September 6, 1999

Proofs received from author(s): March 29, 2000 